\title{
SCREENING OF BIOPROTECTIVE PROPERTIES OF VARIOUS PLANT EXTRACTS AND GAS CHROMATOGRAPHY-MASS SPECTROMETRY PROFILING OF ADENANTHERA PAVONINA STEM EXTRACT
}

\author{
SHUBHA BHADRAN ${ }^{*}$, SANGEETHA ANNIE GEORGE ${ }^{2}$, SUDHAKAR MALLA ${ }^{3}$, HARINI BP ${ }^{4}$ \\ ${ }^{1}$ Department of Genetics, Indian Academy Centre for Research \& Post Graduate Studies, Bengaluru, Karnataka, India. ${ }^{2}$ Department of \\ Zoology, Indian Academy Centre for Research \& Post Graduate Studies, Bengaluru, Karnataka, India. ${ }^{3}$ Department of Biotechnology, \\ Indian Academy Centre for Research \& Post Graduate Studies, Bengaluru, Karnataka, India. ${ }^{4}$ Department of Zoology, Bangalore University, \\ Bengaluru, Karnataka, India. Email: shubhabhadran@yahoo.co.in
}

Received: 25 February 2017, Revised and Accepted: 13 April 2017

ABSTRACT

Objective: The search for various phytotherapeutic compounds is on rise due to a complex multifactorial phenomenon called drug resistance. The present study investigates the cytotoxic, antioxidant, and antiproliferative potential of methanolic extracts of Clitorea ternatea, Averrhoa bilimbi, Phyllanthus acidus, Tecoma stans, Curcuma aromatica, Anethum graveolens, Adhatoda vasica, Markhamia lutea, Spathodea companulata, and Adenanthera pavonina.

Methods: The plant parts were extracted with methanol and screened for 1,1-diphenyl-2-picrylhydrazyl (DPPH) and 2,2'-azino-bis(3ethylbenzothiazoline-6-sulfonic acid) (ABTS) free radical scavenging abilities. The cytotoxic activity of the extracts was investigated on HeLa and HCT116 cells through 3-(4,5-dimethylthiazol2yl)-2,5-diphenyl tetrazolium bromide (MTT) assay, and cell cycle was analyzed by flow cytometry to determine the antiproliferative activity of the extracts. The stem extract of $A$. pavonina was further subjected to gas chromatography-mass spectrometry (GC-MS) analysis for purification of the compounds of interest. A two-way ANOVA was done to estimate the effect of the extract between samples remembered at $\mathrm{p}<0.05$ level.

Results: Among all the studied samples, the extract of A. pavonina (stem) showed significant scavenging activity of $70.23 \%$ and $76.32 \%$ of scavenging compared to $74.58 \%$ and $81.13 \%$ of that of reference standard in ABTS and DPPH assay, respectively. GC-MS analysis of the extract revealed the presence of 17 phytocompounds. MTT assay revealed that this extract (SB19) had promising cytotoxic activity against the two cancer cell lines, HCT116 and HeLa with inhibitory concentration $50 \% \mathrm{IC}_{50}$ values of $25.86 \pm 0.21 \mu \mathrm{g} / \mathrm{ml}$ and $39.89 \pm 0.11 \mu \mathrm{g} / \mathrm{ml}$, respectively. The extract treatment caused significant arrest in G2M phase of cell cycle.

Conclusion: A. pavonina (stem) extract displayed significant antioxidant and antiproliferative activity and can be considered as a potential candidate drug for anticancer studies.

Keywords: Antioxidants, 3-(4,5-dimethylthiazol2yl)-2,5-diphenyl tetrazolium bromide assay, Antiproliferative, Gas chromatography-mass spectrometry, Adenanthera pavonina.

(c) 2017 The Authors. Published by Innovare Academic Sciences Pvt Ltd. This is an open access article under the CC BY license (http://creativecommons. org/licenses/by/4. 0/) DOI: http://dx.doi.org/10.22159/ajpcr.2017.v10i7.18141

\section{INTRODUCTION}

Plants are natural source of novel therapeutics as they contain various phytoconstituents which serve as a source of bioactive compounds with significant pharmacological action. These phytochemicals are referred to as secondary metabolites which are formed during the plants' normal metabolic processes [1] and include alkaloids, flavonoids, coumarins, glycosides, gums, polysaccharides, phenols, tannins, terpenes, and terpenoids [2]. Oxidative stress is caused by free radicals which are produced in our body due to aerobic respiration and substrate oxidation [3-7]. When these free radicals are present in excess, they exert oxidative damage to cellular biomolecules such as membrane lipids, cellular proteins, DNA, and enzymes, eventually leading to many chronic diseases. However, the antioxidant actions of endogenous enzymes as well as natural and synthetic antioxidants can balance the production of free radicals [8,9]. Mode of action of antioxidants includes several mechanisms such as prevention of chain initiation, decomposition of peroxidases, radical scavenging, chelating of transition metal ion catalysts, and prevention of continued hydrogen abstraction [10].

Research suggests that phytochemicals found in botanicals may help in combating various diseases including cancer, heart disease, stroke, high blood pressure, cataracts, osteoporosis, and urinary tract infections and in slowing the aging process. Being rich source of antioxidants, consumption of several plants was recommended $[11,12]$. Cancer is the second biggest killer after heart disease in India and the data from the WHO World Cancer Report released in 2015 indicate that in India, there are 7 lakh new cancer cases per year, killing over 3.5 lakh people every year. Certain preclinical studies provide evidence that phytochemicals can prevent colorectal cancer and other cancers due to their polyphenol antioxidant and anti-inflammatory effects [13-15].

The present work was thus planned with the aim to explore the bioactivities of these plant extracts by assessing their cytotoxic, antiproliferative, and antioxidant efficacy. Based on earlier investigation carried out for evaluation of their antifungal activity on Candida glabrata and screening of phytoconstituents and the current assessment, the active stem extract of Adenanthera pavonina was further subjected to gas chromatography-mass spectrometry (GC-MS) analysis for identification of the components present in the extract.

\section{METHODS}

Plant material

Fresh plant parts were collected during January to June 2013 from various regions in Bengaluru, Karnataka, India. Identification and authentication of the plants were done by Dr. Ramakrishna $\mathrm{T} \mathrm{M}$, 
Department of Biological and Life Science, Bangalore University, and documented with their characteristic features. Plant material was washed, shade-dried and then homogenized to fine powder, and stored in airtight bottles with proper labeling for future use. The labeling provided for various plant parts were as follows: SB1 (Clitorea ternatea leaf), SB2 (C. ternatea flower), SB3 (Averrhoa bilimbi fruit), SB4 (A. bilimbi leaf), SB5 (Phyllanthus acidus leaf), SB6 (P. acidus fruit), SB7 (Tecoma stans flower), SB8 (T. stans leaf), SB9 (Curcuma aromatica leaf), SB10 (C. aromatica rhizome), SB11 (Anethum graveolens leaf), SB12 (A. graveolens stem), SB13 (Adhatoda vasica leaf), SB14 (A. vasica flower), SB15 (Markhamia lutea leaf), SB16 (M. lutea flower), SB17 (Spathodea companulata leaf), SB18 (S. companulata flower), SB19 (Adenanthera pavonina stem), and SB20 (A. pavonina leaf).

The chemicals methanol, ethanol, dimethyl sulfoxide (DMSO), ammonium per sulfate, triton were procured from qualigens; 1,1-diphenyl-2-picrylhydrazyl (DPPH), quercetin, colchicine, and propidium iodide (PI) were purchased from Sigma-Aldrich, USA. 2,2'-azino-bis(3-ethylbenzothiazoline-6-sulfonic acid) (ABTS) solution, 3-(4,5-dimethylthiazol2yl)-2,5-diphenyl tetrazolium bromide (MTT) reagent, and RNaseA were procured from Hi-Media, Bengaluru.

\section{Extraction of plant material}

Crude plant extracts were prepared by Soxhlet extraction method, wherein the powdered plant materials were extracted with methanol. The extracts were then taken in a beaker and kept on hot plate and heated at $30-40^{\circ} \mathrm{C}$ till all the solvent got evaporated. Dried extract was kept in refrigerator at $4^{\circ} \mathrm{C}$ for their future use.

\section{ABTS assay}

The assay is performed as per the study by Auddy et al., 2003 [16]. ABTS $7 \mathrm{mM}$ (38.4 mg in $10 \mathrm{ml}$ ) and ammonium persulfate $2.45 \mathrm{mM}(5.59 \mathrm{mg}$ in $10 \mathrm{ml}$ ) were prepared in phosphate buffer saline (PBS, pH 7.4). ABTS radical cations are produced by reacting ABTS $(7 \mathrm{mM})$ and ammonium persulfate $(2.45 \mathrm{mM})$ and incubating the mixture at room temperature in dark for $16 \mathrm{hrs}$. The solution thus obtained is further diluted with PBS to give an absorbance of 1.000. Different concentrations of the methanolic plant extracts and the reference standard quercetin $(1 \mathrm{mg}$ in $10 \mathrm{ml}$ PBS) are added to $950 \mu \mathrm{ml}$ of ABTS working solution to give a final volume of $1 \mathrm{ml}$, made up by adding PBS. The absorbance is recorded immediately at $734 \mathrm{~nm}$. The percent inhibition is calculated at different concentrations and the inhibitory concentration 50\% $\left(\mathrm{IC}_{50}\right)$ values are calculated by Log-Probit analysis. The inhibition was calculated in following way: $I(\%)=100 \times\left(A_{0}-A_{1}\right) / A_{0}$; where $A_{0}$ is the absorbance of the control, $\mathrm{A}_{1}$ is the absorbance of the extract/standard. A percent inhibition versus concentration curve was plotted, and the concentration of sample required for $50 \%$ inhibition was determined and expressed as $\mathrm{IC}_{50}$ value. The lower the $\mathrm{IC}_{50}$ value indicates high antioxidant capacity.

\section{DPPH assay}

Screenings of antioxidant activity of the extracts were carried out by DPPH free radical scavenging assay $[17,18]$ using ultraviolet spectrophotometric methods. According to the protocol, $200 \mu \mathrm{L}$ of test solutions from different extracts was dissolved in methanol. This solution was then combined with $1.8 \mathrm{ml}$ of DPPH methanol solution. After being mixed, solutions were kept at room temperature, in the dark for 30 minutes incubation. After the reaction, the absorbance was recorded at $517 \mathrm{~nm}$. Methanol was used as a blank, DPPH solution was used as negative control $\left(\mathrm{A}_{0}\right)$, and quercetin $(20 \mathrm{mg} / \mathrm{ml})$ was used as positive control standard. The antioxidant activity was given in terms of $\mathrm{IC}_{50}$ value. All the experiments were carried out in triplicates. The $\%$ scavenging effect was obtained from the formula: scavenging effect $(\%)=\left(A_{0}-A_{1}\right) / A_{0} \times 100$, where $A_{0}$ was the absorbance of the control reaction and $A_{1}$ was the absorbance of the sample of the tested extracts. Percentage of inhibition was calculated using the following formula: \% inhibition $=\left[\left(A_{\text {negative }}-A_{\text {test }}\right) / A_{\text {negative }}\right] \times 100(\mathrm{~A}$ is absorbance $)$.

\section{Cytotoxicity assay}

Cytotoxic activity of methanolic plant extracts against two cancer cell lines was evaluated by MTT assay. HeLa and HCT-116 cell lines were cultured and grown in Dulbecco's modified eagle medium (DMEM) containing $10 \%$ fetal bovine serum (FBS) and $2 \%$ antibiotic and maintained at $37^{\circ} \mathrm{C}$ in $5 \% \mathrm{CO}_{2}$ for $24 \mathrm{hrs}$ in a humid environment. 50,000 cells of HeLa and HCT-116 cell lines were plated in triplicates in 96-well plates with DMEM and incubated for $24 \mathrm{hrs}$ at $37^{\circ} \mathrm{C}$. Varying concentration of plant extracts was taken in FBS-free DMEM and incubated for $24 \mathrm{hrs} .100 \mu \mathrm{l}$ of $5 \mathrm{mg} / 10 \mathrm{ml}$ MTT solution in PBS was added to each well and incubated for 2-3 hrs. After incubation, MTT reagent was discarded. $100 \mu \mathrm{l}$ of DMSO was added to each well that will dissolve the formazan crystals. The plates were read at $590 \mathrm{~nm}$ using a microplate reader. Percent viability is calculated using the formula: \% cell viability $=(O D$ control $-O D$ sample $) / O D$ control $\times 100$.

\section{Cell cycle analysis}

$1 \times 10^{6}$ cells from HCT-116 and HeLa cell cultures were seeded in 6-well plates containing $2 \mathrm{ml}$ of complete DMEM, were plated in two different independent experimental setups, and were grown for $24 \mathrm{hrs}$ in $5 \% \mathrm{CO}_{2}$ incubator at $37^{\circ} \mathrm{C}$. After $24 \mathrm{hrs}$ of incubation, cells are treated with or without 200 and $320 \mu \mathrm{g} / \mathrm{ml}$ A. pavonina stem extract. $20 \mu \mathrm{M}$ colchicine was used as positive control and $1 \% \mathrm{DMSO}$ as negative control in $1 \mathrm{ml} /$ well of DMEM and was incubated for $24 \mathrm{hrs}$. Thereafter, cells were collected and pelleted at $1500 \mathrm{rpm}$ for 5 minutes at room temperature and the supernatant was discarded. The pellet was resuspended gently in $1 \times$ PBS and was fixed overnight at $4^{\circ} \mathrm{C}$ in $2 \mathrm{ml}$ of fixing solution $(20 \% \mathrm{PBS}$ in $70 \%$ ethanol). The suspension was centrifuged at $4000 \mathrm{rpm}$ for 10 minutes at room temperature and the supernatant was discarded. Cells were washed twice with ice-cold $1 \times$ PBS. Later, cells were incubated for 15 minutes or $1 \mathrm{hr}$ at room temperature in $500 \mu \mathrm{l}$ of PI solution containing $0.05 \mathrm{mg} / \mathrm{ml}$ PI and $0.05 \mathrm{mg} / \mathrm{ml}$ RNase A in PBS. The percentage of cells in various stages of cell cycle in compounds treated and untreated populations was determined using FACSCalibur (BD Biosciences, San Jose, CA).

\section{GC-MS analysis}

A GC-MS analysis was performed to study the phytochemical components present in the methanol extract of stem of A. pavonina. GC-MS analysis was carried out on a GC Clarus 500 PerkinElmer system comprising a GC-MS instrument employing the following conditions: GC-MS analysis was carried out on a column Restek RtxR - 5, (30 meter

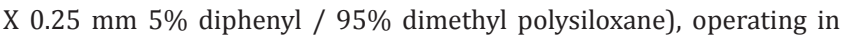
electron impact mode at $70 \mathrm{eV}$. Injection temperature was maintained at $280^{\circ} \mathrm{C}$, helium flow rate as $1 \mathrm{ml} / \mathrm{min}$ and ion source temperature at $230^{\circ} \mathrm{C}$. Injection was performed in the splitless mode and the volume was $1 \mu$ l. The column oven temperature was programmed as $40-280^{\circ} \mathrm{C}$ at a rate of $6^{\circ} \mathrm{C} / \mathrm{min}$ injection mode, wherein the instrument was set to an initial temperature of $40^{\circ} \mathrm{C}$ and was maintained at this temperature for 5 minutes. At the end of this period, the oven temperature was raised up to $280^{\circ} \mathrm{C}$ which was maintained for 15 minutes. The mass spectra of compounds in samples were obtained by electron ionization at $70 \mathrm{eV}$ and in the mass range of 50-700 mass units. Total GC-MS run time is 60 minutes. The essential chemical constituents were identified by interpreting the on mass spectra of GC-MS using the database of National Institute Standard and Technology (NIST) having more than 62,000 patterns. The name, molecular weight, and structure of the compounds of methanol extract of stem of A. pavonina were ascertained.

\section{Statistical analysis}

All of the statistical calculations employed in the present context were carried out with the SPSS10.0. Results were expressed as the mean \pm standard error of triplicates. A two-way ANOVA was used for statistical analysis; $p>0.05$ was considered statistically significant.

\section{RESULTS}

\section{ABTS assay}

The methanol extract of the stems of A. pavonina was fast and effective scavenger of the ABTS radical (Fig. 2) with an $\mathrm{IC}_{50}$ value 
of $19.67 \pm 0.21 \mu \mathrm{g} / \mathrm{ml}$ compared to $5.68 \mu \mathrm{g} / \mathrm{ml}$ of quercetin and the increase in this activity was dose dependent. Methanolic extracts of flower of $A$. vasica and C. aromatica rhizome also exhibited prominent ABTS quenching activity with an $\mathrm{IC}_{50}$ value of $28.23 \pm 0.11$ and $29.57 \pm 0.22 \mu \mathrm{g} / \mathrm{ml}$, respectively. Other plant extracts which exhibited ABTS scavenging activity includes $P$. acidus leaf, $T$. stans leaf, A. vasica leaf, $S$. companulata leaf, and M. lutea flower with $\mathrm{IC}_{50}$ values $36.61 \pm 0.05,37.71 \pm 0.11,40.23 \pm 0.22,41.25 \pm 0.12$, and $53.2 \pm 0.10 \mu \mathrm{g} / \mathrm{ml}$, respectively. The extracts of $A$. pavonina stem, P. acidus leaf, $A$. vasica flower, $C$. aromatica rhizome, $T$. stans leaf, $S$. companulata leaf, $A$. vasica leaf, and M. lutea exhibited percentage inhibition of $70.23 \%, 64.13 \%$, $63.93 \%, 58.58 \%, 57.05 \%, 56.49 \%, 51.24 \%$, and $33.51 \%$, respectively, compared to $74.58 \%$ of quercetin at $100 \mu \mathrm{g} / \mathrm{ml}$ concentration (Fig. 1). A two-way ANOVA between the concentration and different samples was conducted to compare the effect of samples on ABTS scavenging activity. There was a significant effect of different samples remembered at $\mathrm{p}<0.05$ level. The significance effect on the ABTS scavenging activity between the samples and varying concentrations: $F(6,48)=147.3328$, $\mathrm{p}=3.56 \mathrm{E}-29$ and $\mathrm{F}(8,48)=4.386676, \mathrm{p}=0.00497$.

\section{DPPH assay}

Among the plants extracts as seen in DPPH assay, A. pavonina stem extract exhibited highest antioxidant activity with $\mathrm{IC}_{50}$ value of $25.01 \pm 0.25 \mu \mathrm{g} / \mathrm{ml}$ compared to $4.411 \mu \mathrm{g} / \mathrm{ml}$ of the standard quercetin. Other plant extracts which exhibited antioxidant activity were P. acidus leaf, $T$. stans leaf, $M$. lutea flower, $S$. companulata leaf with $\mathrm{IC}_{50}$ value of $43.23 \pm 0.31,43.6 \pm 0.11,53.92 \pm 0.44$, and $35.67 \pm 0.20 \mu \mathrm{g} / \mathrm{ml}$, respectively. The scavenging activity was presented as the percentage of inhibition of DPPH free radicals (Fig. 4), wherein at $100 \mu \mathrm{g} / \mathrm{ml}$ maximum inhibitory effect of $76.32 \%$ was shown by A. pavonina stem extract compared to $81.13 \%$ of reference standard. Other extracts of P. acidus leaf, T. stans leaf, M. lutea flower, S. companulata leaf exhibited $47.89 \%$, 59.87\%, $51.58 \%$, and $55.89 \%$ of inhibition, respectively (Fig. 3). A two-way ANOVA between the concentration and different samples was conducted to compare the effect of samples on DPPH scavenging activity. There

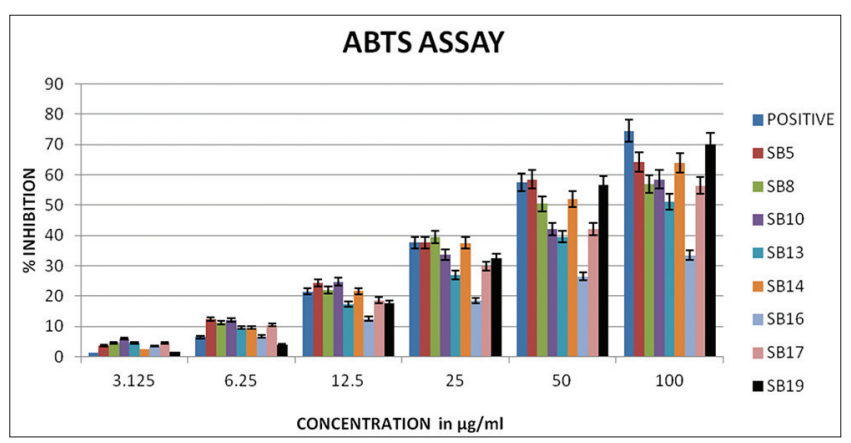

Fig. 1: The percentage inhibition of 2,2'-azino-bis(3ethylbenzothiazoline-6-sulfonic acid) assay. All the values were average of triplicates. Quercetin is used as positive control

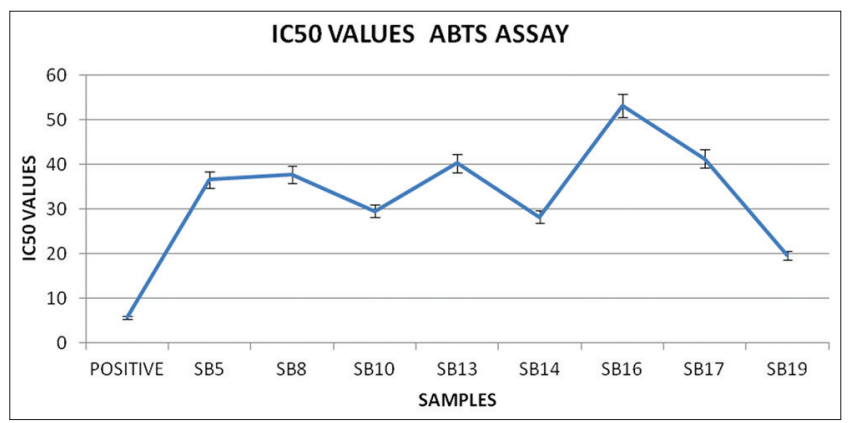

Fig. 2: The inhibitory concentration $50 \%$ values of 2,2 '-azinobis(3-ethylbenzothiazoline-6-sulfonic acid) assay. All the values were average of triplicates was a significant effect of different samples remembered at $\mathrm{p}<0.05$ level. The significance effect on the DPPH scavenging activity between the samples and varying concentrations, $F(6,36)=60.584, p=2.44 \mathrm{E}-17$ and $\mathrm{F}(6,36)=8.512926, \mathrm{p}=0.00517$.

\section{MTT assay}

Among the various plant extracts used for the assay extracts of A. bilimbi leaf, P. acidus leaf, $A$. vasica leaf, M. lutea leaf, and A. pavonina stem demonstrated cytotoxic effect on HeLa cells (Fig. 7) with $\mathrm{IC}_{50}$ values $72.35 \pm 0.23,57.83 \pm 0.13,91.23 \pm 0.31,81.12 \pm 0.33$, and $39.89 \pm 0.11 \mu \mathrm{g} / \mathrm{ml}$, respectively. These same plant extract samples have shown dose-dependent manner of cytotoxicity in HCT116 cells as well (Fig. 6). The $\mathrm{IC}_{50}$ value of $A$. bilimbi leaf, $P$. acidus leaf, $A$. vasica leaf, $M$. lutea leaf, and $A$. pavonina stem extract was $87.34 \pm 0.41,45.67 \pm 0.05$, $85.72 \pm 0.31,74.53 \pm 0.13$, and $25.86 \pm 0.21 \mu \mathrm{g} / \mathrm{ml}$, respectively (Fig. 7)

\section{Cell cycle analysis}

The effect of A. pavonina stem extract at two different concentrations on cell cycle in HeLa cells and HCT116 cell lines as analyzed by flow cytometry is depicted in Fig. 8. The A. pavonina stem extract treatment on HeLa cells and HCT116 cells has significantly arrested G2M phase of cell cycle at $23.94 \%$ and $15.56 \%$, respectively, at a concentration of $200 \mu \mathrm{g} / \mathrm{ml}$ and $29.86 \%$ and $25.37 \%$, respectively, at a concentration of $320 \mu \mathrm{g} / \mathrm{ml}$ compared to untreated cells with $18.93 \%$ and $14.45 \%$ arrest, respectively. Colchicine has exhibited a cell cycle arrest of HeLa cells and HCT116 cells at $48.38 \%$ and $50.33 \%$, respectively, in G2M phase (Fig. 9).

\section{GC-MS analysis}

The test sample A. pavonina stem extract was subjected to GC-MS and the total separated peaks are shown in Fig. 10. The mass of the compounds and fragments recorded were matched with NIST database for identification of probable compounds present in the sample. All 17 compounds were identified from the GC-MS analysis of the sample SB19 extract exhibiting various phytochemical activities

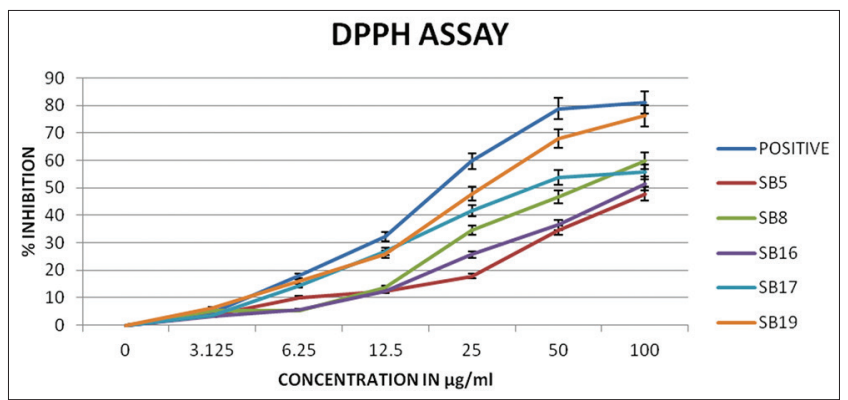

Fig. 3: The percent inhibition of 1,1-diphenyl-2-picrylhydrazyl assay. All the values were average of triplicates. Quercetin is used as positive control

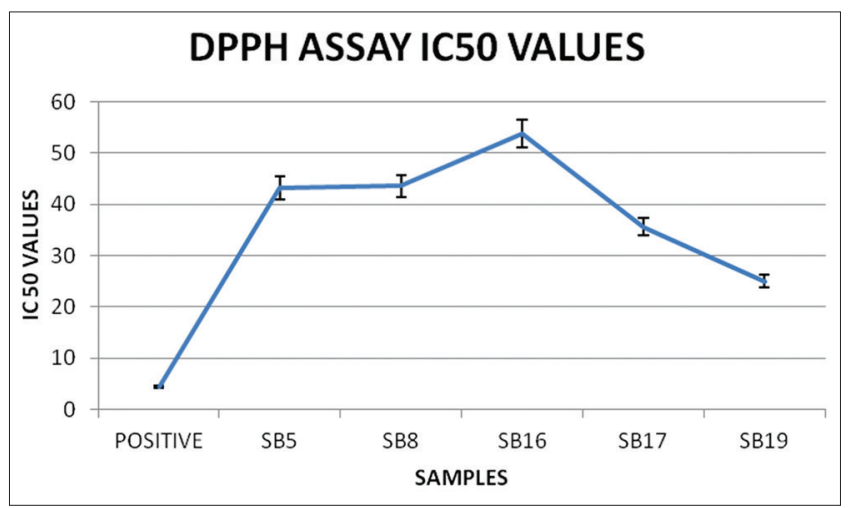

Fig. 4: The inhibitory concentration $50 \%$ values of 1,1-diphenyl-2picrylhydrazyl assay. All the values were average of triplicates 


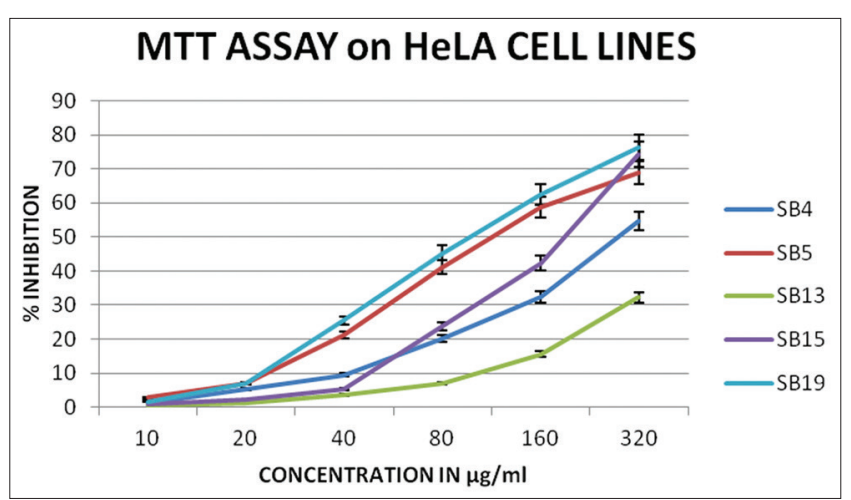

Fig. 5: The 3-(4, 5-dimethylthiazol2yl)-2, 5-diphenyl tetrazolium bromide cytotoxicity values of the extracts on HeLa cell lines. All the values were average of triplicates $\% \pm$ standard error

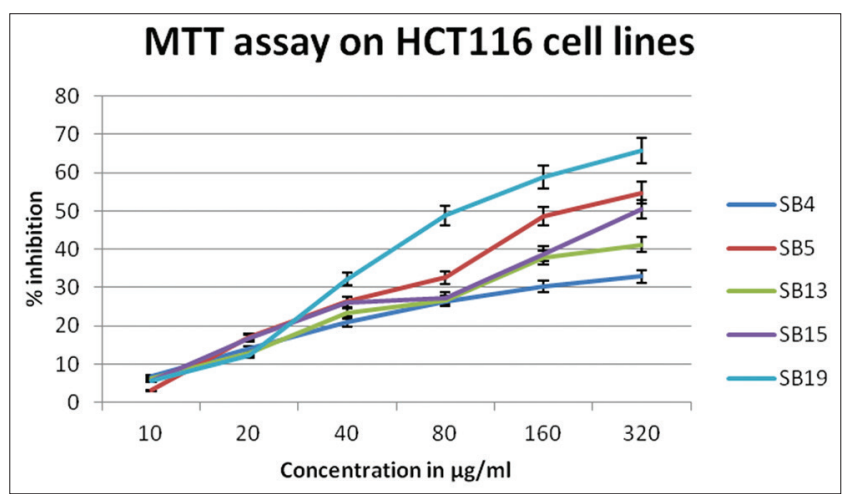

Fig. 6: The percent inhibition values of the extracts obtained in 3-(4,5-dimethylthiazol2yl)-2,5-diphenyl tetrazolium bromide assay on HCT116 cell lines. All the values were average of triplicates $\% \pm$ standard error

and were predominantly responsible for the antifungal activity found in the extract against the pathogenic species mentioned. The retention time and percentage peak of various bioactive compounds are presented in Table 1 . The major phytoconstituents present in the stem extracts of A. pavonina were isobutyl nitrate, 3,4 hexane dione, oxalic acid butyl propyl ester, isonitropropane, oxalic acid, ally pentyl ester, 2-benzyl-1,3-dioxolane, 1,3-dioxolane, 2-benzyl-1,3-dioxolane, cyclopentasiloxane, $\quad[(2,4,4,6,6,8,8$-heptamethylcyclotetrasiloxan2-yl)oxy]nonamethyl-, $\quad$ 2-heptyl-1,3-dioxolane, $\quad 3$-ethoxy1,1,1,7,7,7-hexamethyl-3,5,5-tris tetrasiloxane, malonic acid, bis(2-trimethylsilylethyl ester, acetic acid, [o-(trimethylsiloxy) pentyl]-, trimethylsilyl ester, methyl-alpha--d-ribofuranoside, 3-methylmannoside, 2,3,4,5-tetrahydroxypentanal, and methyl 4-o-methyl-d-arabinopyranoside.

\section{DISCUSSION}

In recent years, various research validations have accentuated the importance of antioxidants in prevention and treatment of diseases by reducing the deleterious effects of free radicals [19]. Free radicals are one of the major factors responsible for inducing DNA mutation through various oxidative processes, resulting in the initiation of carcinogenesis [20]. The antioxidants through their ability to quench the free radicals and reactive oxygen bring about regression of premalignant lesions and inhibit their development into cancer [21]. Furthermore, the endogenous antioxidant system responsible for preventing the formation of free radicals in the body can be improved by supplementing natural sources with antioxidant property [22]. Botanicals being a rich source of antioxidants act as efficient free radical scavengers and play significant role in chemoprevention.

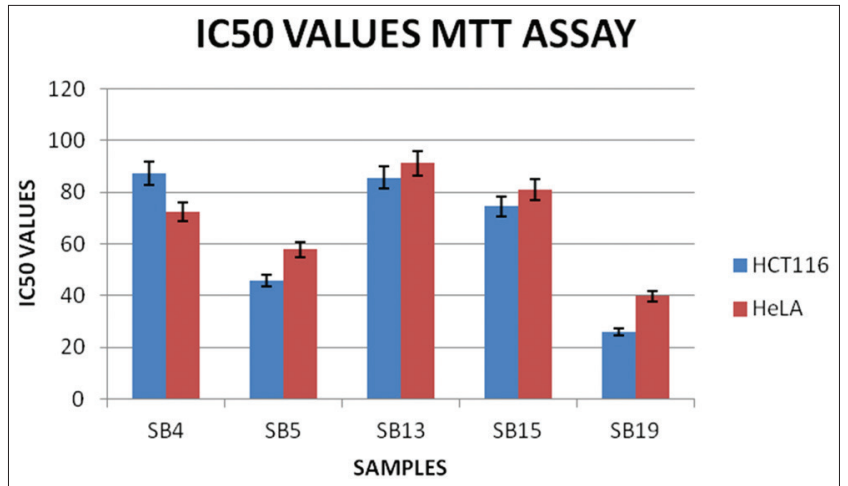

Fig. 7: The inhibitory concentration $50 \%$ values of the extracts obtained in 3-(4,5-dimethylthiazol2yl)-2,5-diphenyl tetrazolium bromide assay on both the cell lines, HCT116 and HeLa. All the values were average of triplicates

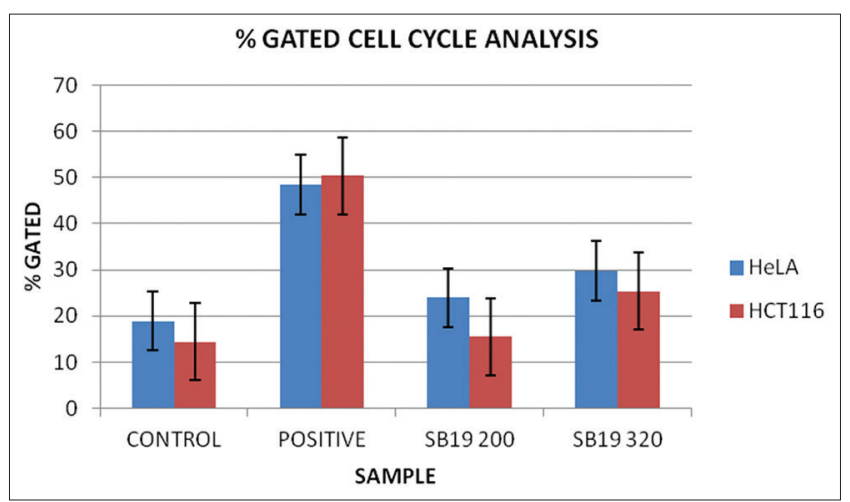

Fig. 8: The percent cell viability values at G2M phase. All the values were average of triplicates. The values were expressed as $\% \pm$ standard error. The cell viability assay was done on both HeLa and HCT116 cell lines

In the present investigation, the result of ABTS assay indicated that among the eight plant extracts which demonstrated antioxidant activity A. pavonina stem exhibited most potent ABTS scavenging activity. Based on the percentage inhibition, the plant extracts can be ranked in the following descending order: A. pavonina stem $>$ P. acidus leaf $>$ A. vasica flower $>C$. aromatica rhizome $>T$. stans leaf $>S$. companulata leaf $>$ A. vasica leaf $>M$. lutea flower. The DPPH assay results revealed that A. pavonina stem extract exhibited most promising antioxidant activity followed by extracts of $S$. companulata leaf, $P$. acidus leaf, T. stans leaf, and M. lutea flower.

Studies on these plants by other researchers also indicate their radical scavenging activity. Strong antioxidant activity is shown by aqueous extract of the decoction prepared with barks of A. pavonina and Thespesia populnea with an effective concentration $50 \%\left(\mathrm{EC}_{50}\right)$ value of $7.24 \pm 0.49 \mu \mathrm{g} / \mathrm{ml}$ [23], and also, it is demonstrated that the bark extract of $A$. pavonina has an $\mathrm{EC}_{50}$ value of $58.68 \mu \mathrm{g} / \mathrm{ml}$ [24]. The methanolic extract of fruit part of $P$. acidus exhibits moderate to good antioxidant activity in a dose-dependent manner and is found to contain flavonoid compounds [25]. Strong antioxidant properties were confirmed in the ethanol and methanol extract fractions of T. stans, wherein at a concentration of $0.1 \mathrm{mg} / \mathrm{ml}$, the scavenging activity of ethanol and methanol extracts [26] reached $56.88 \%$ and $58.92 \%$. Research reveals that the antioxidant mechanisms of $S$. companulata flower and bark extracts are distinct from each other and they present significant antioxidant capacity within a biological system in the presence of $\mathrm{Fe}^{3+}$ ascorbic acid [27]. Certain species of Markhamia such as the Morchella tomentosa methanolic extract indicate high DPPH radical scavenging capacity and antioxidant activity [28]. High concentration of antioxidant 


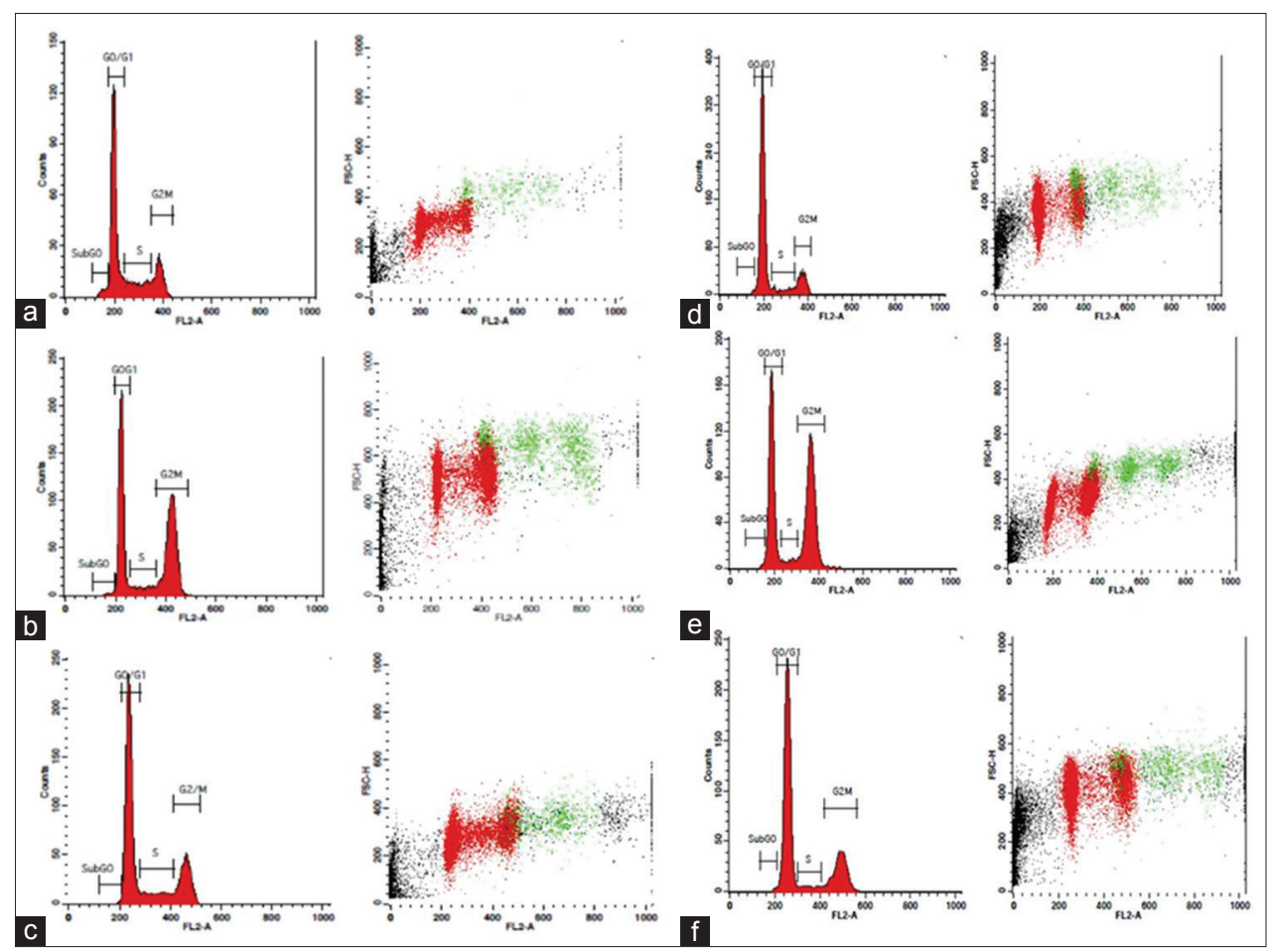

Fig. 9: Flow cytometry plots of the test sample Adenanthera pavonina stem extract against HeLa and HCT116 cell lines. (a) HeLa cells treated with $1 \%$ dimethyl sulfoxide (DMSO) as control; (b) HeLa cells treated with $20 \mu \mathrm{M}$ of colchicine; (c) HeLa cells treated with $200 \mu \mathrm{g} / \mathrm{ml}$ of test sample extract; (d) HCT116 cells treated with 1\% DMSO as control; (e) HCT-116 cells treated with $20 \mu \mathrm{M}$ of colchicine; (f) HCT116 cells treated with $320 \mu \mathrm{g} / \mathrm{ml}$ of test sample extract

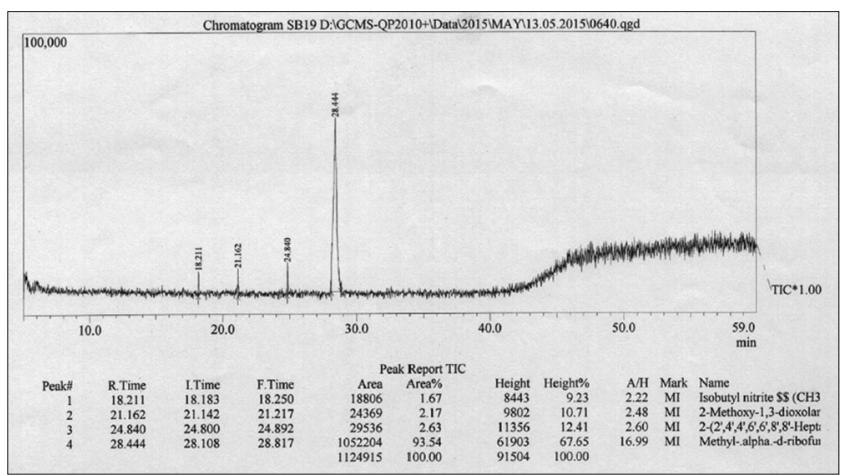

Fig. 10: Gas chromatography-mass spectrometry chromatograms of methanolic extract from the stem of Adenanthera pavonina (SB19)

phytochemicals such as polyphenolic compounds and flavonoids are present in A. vasica and thus the plant shows strong total antioxidant activity [29].

Investigation on the cytotoxic efficacy of various plant extracts on HeLa and HCT116 cell line by utilizing high-throughput MTT assay demonstrated that five of the plant extracts have cytotoxic effect on both HeLa and HCT116 cell line in a dose-dependent manner. A. pavonina stem extract exhibited potent cytotoxic efficacy in both the cell lines. In HeLa cell lines, the extracts of A. pavonina stem, M. lutea leaf, $P$. acidus leaf, $A$. bilimbi leaf, and A. vasica leaf exhibited 76.34\%, $74.35 \%, 68.91 \%, 54.67 \%$, and $32.23 \%$ of cytotoxicity at $320 \mu \mathrm{g} / \mathrm{ml}$, respectively (Fig. 5). Most promising cytotoxicity in HeLa cell lines was thus shown by A. pavonina stem and M. lutea leaf extracts followed by the moderate activity of $A$. bilimbi leaf, $P$. acidus leaf extract and mild activity of $A$. vasica leaf extract. In HCT116 cell lines, the plant extracts of A. pavonina stem, P. acidus leaf, M. lutea leaf, A. vasica leaf, and $A$. bilimbi leaf demonstrated cytotoxicity of $65.78 \%, 54.77 \%, 50.43 \%$,
$41.23 \%$, and $32.93 \%$ at $320 \mu \mathrm{g} / \mathrm{ml}$, respectively. Among the five plants extracts, A. pavonina stem extract exhibited potent cytotoxic efficacy in both the cell lines. Assessment of cytotoxic potential of methanolic extract of A. bilimbi fruits using brine shrimp lethality bioassay suggests significant activity [30]. Studies reveal significant in vitro cytotoxic activity of ethyl acetate extract of leaves of P. acidus against Hep G2 and DLA cell lines [31]. A. vasica extract possesses promising anticancer activity [32]. Vasicine acetate obtained by acetylation of the alkaloid vasicine isolated from ethanolic extracts of leaves of A. vasica showed potent cytotoxic activity against A549 lung adenocarcinoma cancer cell with an $\mathrm{IC}_{50}$ value of $2000 \mu \mathrm{mg} / \mathrm{mL}$. The decoction containing A. pavonina L. and T. populnea L bark extracts possesses potent antiproliferative and cytotoxic activities (Silva et al., 2011).

Based on the results of antioxidant assay and cytotoxicity assay, A. pavonina stem extract was subjected to assessment of antiproliferative activity on HeLa and HCT116 cell lines by flow cytometry analysis. The investigation revealed that $A$. pavonina stem extract significantly arrests the cell cycle at G2M phase and induces apoptosis.

In addition, the present study aimed to isolate the phytoconstituents by GC-MS profiling of active plant extract. Thus, the following phytoconstituents were isolated from the stem extract of $A$. pavonina: Isobutyl nitrate, 3,4 hexane dione, oxalic acid butyl propyl ester, isonitropropane, oxalic acid, allypentyl ester, 2-benzyl-1,3dioxolane, 1,3-dioxolane, 2-benzyl-1,3-dioxolane, cyclopentasiloxane, [(2,4,4,6,6,8,8-heptamethylcyclotetrasiloxan-2-yl)oxy]nonamethyl-, 2-heptyl-1,3-dioxolane, 3-ethoxy-1,1,1,7,7,7-hexamethyl-3,5,5-tris tetrasiloxane, malonic acid, bis(2-trimethylsilylethyl ester, acetic acid,[o-(trimethylsiloxy)pentyl]-, trimethylsilyl ester, methyl-alpha.-dribofuranoside, 3-methylmannoside, 2,3,4,5-tetrahydroxypentanal, and methyl 4-o-methyl-d-arabinopyranoside.

Among the various organic acids evaluated for their antifungal activity oxalic acid has exhibited a potent antifungal effect on the growth of four fungal species Aspergillus flavus, Penicillium purpurogenum, 
Table 1: The phytochemical constituents obtained on GC chromatogram with NIST library match

\begin{tabular}{|c|c|c|c|c|}
\hline S. No. & $\mathbf{R}_{\text {index }}$ & Compound name & Molecular formula & Molecular weight \\
\hline \multicolumn{5}{|c|}{ GC chromatogram with NIST library match of peaks with RT 18.208 minutes } \\
\hline 1 & 544 & Isobutyl nitrate & $\mathrm{C}_{4} \mathrm{H}_{9} \mathrm{NO}_{2}$ & 103 \\
\hline 2 & 1039 & 3,4 hexane dione & $\mathrm{C}^{4} \mathrm{H}_{16} \mathrm{O}_{2}$ & 156 \\
\hline 3 & 1250 & Oxalic acid butyl propyl ester & $\mathrm{C}_{9} \mathrm{H}_{16} \mathrm{O}_{4}{ }_{4}$ & 188 \\
\hline 4 & 637 & Isonitropropane & $\mathrm{C}_{3} \mathrm{H}_{7} \mathrm{NO}_{2}$ & 8 \\
\hline 5 & 1340 & Oxalic acid, ally pentyl ester & $\mathrm{C}_{10}^{3} \mathrm{H}_{16} \mathrm{O}_{4}^{2}$ & 200 \\
\hline \multicolumn{5}{|c|}{ GC chromatogram with NIST library match of peaks with RT 21.152 minutes } \\
\hline 7 & 578 & 1,3-dioxolane & $\mathrm{C}_{3} \mathrm{H}_{6} \mathrm{O}_{2}$ & 74 \\
\hline 8 & 1312 & 2-benzyl-1,3-dioxolane & $\mathrm{C}_{10}^{3} \mathrm{H}_{12}^{0} \mathrm{O}_{2}$ & 164 \\
\hline \multicolumn{5}{|c|}{ GC chromatogram with NIST library match of peaks with RT 24.842 minutes } \\
\hline 9 & 1716 & $\begin{array}{l}\text { Cyclopentasiloxane, [(2,4,4,6,6,8,8-heptamethylcyclotetrasiloxan-2-yl) } \\
\text { oxy] nonamethyl- }\end{array}$ & $\mathrm{C}_{16} \mathrm{H}_{48} \mathrm{O}_{10} \mathrm{Si}_{9}$ & 652 \\
\hline 10 & 1235 & 2-heptyl-1,3-dioxolane & $\mathrm{C}_{10} \mathrm{H}_{20} \mathrm{O}_{2}$ & 172 \\
\hline 11 & 1612 & 3-ethoxy-1,1,1,7,7,7-hexamethyl-3,5,5-tris tetrasiloxane & $\mathrm{C}_{17}^{10} \mathrm{H}_{50} \mathrm{O}_{7} \mathrm{Si}_{7}$ & 562 \\
\hline 12 & 1468 & Malonic acid, bis (2-trimethylsilylethyl ester & $\mathrm{C}_{13} \mathrm{H}_{28} \mathrm{O}_{4} \mathrm{Si}_{2}^{\prime}$ & 304 \\
\hline \multicolumn{5}{|c|}{ GC chromatogram with NIST library match of peaks with RT 28.442 minutes } \\
\hline 14 & 1406 & Methyl-alpha.-d-ribofuranoside & $\mathrm{C}_{6} \mathrm{H}_{12} \mathrm{O}_{5}$ & 164 \\
\hline 15 & 1714 & 3-methylmannoside & $\mathrm{C}_{7} \mathrm{H}_{14} \mathrm{O}_{6}$ & 194 \\
\hline 16 & 1436 & 2,3,4,5-tetrahydroxypentanal & $\mathrm{C}_{5} \mathrm{H}_{10} \mathrm{O}_{5}$ & 150 \\
\hline 17 & 1359 & Methyl 4-o-methyl-d-arabinopyranoside & $\mathrm{C}_{7} \mathrm{H}_{14} \mathrm{O}_{5}$ & 178 \\
\hline
\end{tabular}

NIST: National Institute Standard and Technology, GC: Gas chromatography

Rhizopus nigricans, and Fusarium oxysporum, wherein the high acidity appeared for oxalic acid was 0.14 at a high concentration of $10 \%$ [33]. Oxalic acids may exhibit antioxidant properties by chelating $\mathrm{Fe}^{2+}$. This ability of oxalic acid is of great importance as it reduces the availability of $\mathrm{Fe}^{2+}$ for oxidation by $\mathrm{H}_{2} \mathrm{O}_{2}$ to generate the highly reactive hydroxyl radicals. 1,3-dioxolanes exhibited significant antifungal activity against Candida albicans while most of the compounds have also shown significant antibacterial activity against Staphylococcus aureus, Staphylococcus epidermidis, Enterococcus faecalis, and Pseudomonas aeruginosa [34]. The antimycotic effect of six new polyazole derivatives from 2-(2,4-dichlorophenyl)-1,3-dioxolane was studied against pathogenic fungi for humans and animals. Remarkable effect was shown by these compounds on filamentous fungi Aspergillus fumigatus and Scedosporium apiospermum which were as effective as the two references ketoconazole and oxiconazole [35].

The apoptotic and cytotoxic effects of the alpha-diketone derivatives 2,3- and 3,4-hexanediones were investigated in three non-neuronal cell lines (MCF7, HepG (2), and CaCo-2) and in the neuroblastoma line, SH-SY5Y. 2,3- and 3,4-hexanediones showed apoptosis over the concentration range 1-1.6 mM, with 3,4-hexanedione being the more potent compared to the 2,3-isomer. These alpha-diketones may also have therapeutic implications as they display a degree of toxic selectivity toward neuroblastoma cells [36]. Studies were carried out to compare the cytotoxic potentiality of hexanedione food additives (2,3- and 3,4 isomers) with that of neurotoxic hexane metabolite 2,5-hexanedione in the human SK-N-SH neuroblastoma line. The $\mathrm{IC}_{50}$ value of 3 ,4-hexanedione $(3.5 \pm 0.1 \mathrm{mM})$, indicated that this compound has approximately seven-fold greater toxic effect on cells compared with that of 2,5 derivative $\left(\mathrm{IC}_{50}=22.4 \pm 0.2 \mathrm{mM}\right)$. Similarly, flow cytometry indicated that the 3,4-hexanedione derivative caused interruption in the neuroblastoma cell cycle and induced apoptosis up to $60.4 \pm 0.5 \%$ [37]. 2-benzyl-1,3-dioxolane exhibits a broad spectrum of biological activities such as antifungal [38], antibacterial [39,40], and antineoplastic [41] activities.

\section{CONCLUSION}

The search for such natural products has revolutionized the drug discovery program. The present study revealed the pharmacological potentials of various plants among which A. pavonina stem extract exhibited promising antioxidant, cytotoxic, and antiproliferative potential. To the best of our knowledge, this is the first report on the antiproliferative activity of $A$. pavonina stem extract on HeLa and HCT116 cell lines and its phytoconstituent characterization by GC-MS technique. Thus, these plants can be further studied for the development of new effective anticancer drugs.

\section{REFERENCES}

1. Okigbo RN, Anuagasi CL, Amadi JE. Advances in selected medicinal and aromatic plants indigenous to Africa. J Med Plants Res 2009;3(2):86-95.

2. Okwu DE. Phytochemicals and vitamin content of indigenous spices of South Eastern Nigeria. J Sustain Agric Environ 2004;6:30-4.

3. Moreira P, Smith MA, Zhu X, Honda K, Lee HG, Aliev G, et al. Since oxidative damage is a key phenomenon in Alzheimer's disease, treatment with antioxidants seems to be a promising approach for slowing disease progression. Oxidative damage and Alzheimer's disease: Are antioxidant therapies useful? Drug News Perspect 2005;18:13-9.

4. Paz-Elizur T, Sevilya Z, Leitner-Dagan Y, Elinger D, Roisman LC, Livneh Z. DNA repair of oxidative DNA damage in human carcinogenesis: Potential application for cancer risk assessment and prevention. Cancer Lett 2008;266(1):60-72.

5. Naito Y, Uchiyama K, Yoshikawa T. Oxidative stress involvement in diabetic nephropathy and its prevention by astaxanthin. Oxid Stress Dis 2006;21:235-42.

6. Jain SK. Superoxide dismutase overexpression and cellular oxidative damage in diabetes. A commentary on "Overexpression of mitochondrial superoxide dismutase in mice protects the retina from diabetes-induced oxidative stress". Free Radic Biol Med 2006;41(8):1187-90.

7. Heinecke JW. Mechanisms of oxidative damage of low density lipoprotein in human atherosclerosis. Curr Opin Lipidol 1997;8(5):268-74.

8. Halliwell B. How to characterize a biological antioxidant. Free Radic Res Commun 1990;9(1):1-32.

9. Halliwell B. Antioxidants: The basics - What they are and how to evaluate them. Adv Pharmacol 1997;38:3-20.

10. Valko M, Rhodes CJ, Moncol J, Izakovic M, Mazur M. Free radicals, metals and antioxidants in oxidative stress-induced cancer. Chem Biol Interact 2006;160(1):1-40.

11. Wattenberg LW. Chemoprevention of carcinogenesis by minor dietary constituents: Symposium introduction. Pharm Biol 1998;36:6-7.

12. Yang CS, Chung JY, Yang G, Chhabra SK, Lee MJ. Tea and tea polyphenols in cancer prevention. J Nutr 2000;130 2S Suppl:472S-8.

13. Greenberg ER, Baron JA, Tosteson TD, Freeman DH Jr, Beck GJ, Bond $\mathrm{JH}$, et al. A clinical trial of antioxidant vitamins to prevent 
colorectal adenoma. Polyp Prevention Study Group. N Engl J Med 1994;331(3):141-7.

14. Weng CJ, Yen GC. Chemopreventive effects of dietary phytochemicals against cancer invasion and metastasis: Phenolic acids, monophenol, polyphenol, and their derivatives. Cancer Treat Rev 2012;38(1):76-87.

15. Yang CS, Li G, Yang Z, Guan F, Chen A, Ju J. Cancer prevention by tocopherols and tea polyphenols. Cancer Lett 2013;334(1):79-85.

16. Auddy B, Ferreira M, Blasina F, Lafon L, Arredondo F, Dajas F, et al. Screening of antioxidant activity of three Indian medicinal plants, traditionally used for the management of neurodegenerative diseases. J Ethnopharmacol 2003;84(2-3):131-8.

17. Gaitry CP, Binda DS, Farhin I, Sujata SD. Antimicrobial and antioxidant activities of methanol extract roots of Glycyrrhiza glabra and HPLC analysis. Int J Pharm Pharm Sci 2013;5:975-1491.

18. Zahin M, Aqil F, Ahmad I. The in vitro antioxidant activity and total phenolic content of four Indian medicinal plants. Int J Pharm Pharm Sci 2009;1 Suppl 1:88-95.

19. Niki E. Assessment of antioxidant capacity in vitro and in vivo. Free Radic Biol Med 2010;49(4):503-15.

20. Johnson IT. Phytochemicals and cancer. Proc Nutr Soc 2007;66(2):207-15.

21. Langseth L. Oxidants, Antioxidants, and Disease Prevention. Washington, DC, USA: International Life Sciences Institute Press; 1995.

22. Johnson IT. New approaches to the role of diet in the prevention of cancers of the alimentary tract. Mutat Res 2004;551(1-2):9-28.

23. Silva IK, Soysa P. Evaluation of phytochemical composition and antioxidant capacity of a decoction containing Adenanthera pavonina L. and Thespesia populnea L. Pharmacogn Mag 2011;7(27):193-9.

24. Ramli S, Bunrathep S, Tansaringkarn T, Ruangrungsi N. Screening for free radical scavenging activity from ethanolic extract of mimosaceous plants endemic to Thailand. J Health Res 2008;22:55-9.

25. Rahman M, Habib R, Hasan SM, Sayeed MA, Rana S. Antibacterial, cytotoxic and antioxidant potential of methanolic extract of Phyllanthus acidus L. Int J Drug Dev Res 2011;3(2):154-61.

26. Govindappa M, Sadananda TS, Channabasava R, Jeevitha MK, Pooja KS, Raghavendra VB. Antimicrobial, antioxidant activity and phytochemical screening of Tecoma stans (L.) Juss. Ex Kunth. J Phytol 2011;3(3):68-76.

27. Heim SC, Guarnier FA, Ferreira DT, Braz-Filho R, Cecchini R, Cecchini AL. Antioxidant activity of Spathodea campanulata (Bignoneaceae) extracts. Rev Bras Plantas Med Botucatu 2012;14(2):287-92.

28. Aladesanmi AJ, Iwalewa EO, Adebajo AC, Akinkunmi EO, Taiwo BJ, Olorunmola FO, et al. Antimicrobial and antioxidant activities of some Nigerian medicinal plants. Afr J Tradit Complement Altern Med
2006;4(2):173-84

29. Kumar A, Garg VK, Kumar R, Singh L, Chauhan S. Pharmacognostic study and establishment of quality parameters of leaves of Adhatoda vasica. Linn. J Med Plants Stud 2013;1(3):35-40.

30. Kumar KA, Gousia SK, Anupama M, Latha JN. A review on phytochemical constituents and biological assays of Averrhoa bilimbi. Int J Pharm Pharm Sci Res 2013;3(4):136-9.

31. Gopinath G, Sujesh M, Babu TD. Evaluation of cytotoxic and antitumor activity of Phyllanthus acidus (L.) Skeels leaf extracts. Int J Nov Res Life Sci 2015;2(2):19-26.

32. Kulkarni AA. Ray of hope for cancer patients. In: Proceedings of the International Seminar on Holistic Management of Cancer, Ayurvedic Education: Series No. 67; 1998. p. 5-11.

33. Hassan R, El-Kadi S, Mostafa S. Effect of some organic acids on some fungal growth and their toxins production. Int J Adv Biol 2015;2:1-11.

34. Küçük HB, Yusufoglu A, Mataraci E, Dösler S. Synthesis and biological activity of new 1,3-dioxolanes as potential antibacterial and antifungal compounds. Molecules 2011;16(8):6806-15.

35. Delcourt A, Mathieu G, Baji H, Kimny T, Flammang M, Compagnon PL. New polyazole derivatives from 2-(2,4-dichlorophenyl)-1,3-dioxolane. Antifungal activity. Structure-activity relationships. Mycopathologia 1997; 137(1):27-32.

36. Coleman MD, Zilz TR, Griffiths HR, Woehrling EK. A comparison of the apoptotic and cytotoxic effects of hexanedione derivatives on human non-neuronal lines and the neuroblastoma line SH-SY5Y. Basic Clin Pharm Toxicol 2007;102:25-9.

37. Zilz TR, Griffiths HR, Coleman MD. Apoptotic and necrotic effects of hexanedione derivatives on the human neuroblastoma line SK-N-SH. Toxicology 2007;231(2-3):210-4.

38. Baji H, Kimny T, Gasquez F, Flammang M, Compagnon PL, Delcourt A, et al. Synthesis, antifungal activity and structure-activity relationships of 2-(alkyl or aryl)-2-(alkyl or polyazol-1-ylmethyl)-4-(polyazol-1ylmethyl)-1,3-dioxolanes. Eur J Med Chem 1997;32:637-50.

39. Crawley GC, Briggs MT. Chiral dioxolane inhibitors of leukotriene biosynthesis: Structure-activity relationships and syntheses using asymmetric dihydroxylation. J Med Chem 1995;38(20):3951-6.

40. Genta MT, Villa C, Mariani E, Loupy A, Petit A, Rizzetto R, et al. Microwave-assisted preparation of cyclic ketals from a cineole ketone as potential cosmetic ingredients: Solvent-free synthesis, odour evaluation, in vitro cytotoxicity and antimicrobial assays. Int J Pharm 2002;231(1):11-20.

41. Shirai R, Takayama H, Nishikawa A, Koiso Y, Hashimoto Y. Asymmetric synthesis of antimitotic combretadioxolane with potent antitumor activity against multi-drug resistant cells. Bioorg Med Chem Lett 1998;8(15):1997-2000. 